\title{
A Rare Association of Celiac Disease with Turner Syndrome
}

\author{
Ramar $\mathbf{P}^{1}$, Roy Shuvendu ${ }^{2}$ \\ ${ }^{1}$ Dr. Praveen Ramar, MBBS, MD, Graded Specialist \\ in Paediatrics, 92 Base Hospital, ${ }^{2} \mathrm{Dr}$. Shuvendu Roy, \\ MBBS, MD, Senior Adviser (Paediatrics), Army Hospital \\ (R\&R) Delhi Cantt, New Delhi - 110010, India.
}

\section{Introduction}

C liac Disease is an immune - mediated enteropathy caused by permanent sensitivity to gluten in genetically susceptible individuals. It develops after dietary exposure to the protein gluten, which is found in wheat and rye $^{1}$. Although it is primarily an enteropathy, it may manifest with a number of extra-intestinal manifestations ${ }^{2}$. We report one such rare presentation of Celiac Disease.

\section{The Case}

This 13 year old girl presented with effort intolerance and easy fatigability of eight years duration. Clinically she was found to have severe pallor. However, there was no rash, lymphadenopathy, organomegaly or bone tenderness. Anthropometry revealed severe stunting with proportionate short stature [Weight $-21 \mathrm{~kg}(45 \%$ of 50th centile). Height $-110 \mathrm{cms}$ (less than $3 \mathrm{rd}$ centile) but a normal weight for height.She was also found to have short neck and preadolescent features in SMR staging (SMR Stage II). Systemic examination was essentially within normal limits.

Investigations revealed dimorphic anemia $[\mathrm{Hb}-4.6$ $\mathrm{gm} \%]$ with normal urinalysis, chest X-ray and tuberculin test. The bone age was between $11-13 \mathrm{yrs}$, which approximates the chronological age but exceeds the height age $\left(5 \frac{1}{4}\right.$ years). The results are summarized in Table 1.

In view of the presence of severe stunting and severe anemia, possibility of malabsorption syndrome was entertained and she was investigated accordingly. The anti-tissue trans-glutaminase (TTG) IgA titre was 298 units (normal range - less than 20 units) which was suggestive of Celiac Disease. Small intestinal biopsy was also done which confirmed the diagnosis (flattening

\section{Address for correspondence \\ Dr. Praveen Ramar \\ E-mail: praveen.army@gmail.com}

\begin{abstract}
Celiac Disease is an immune mediated enteropathy, with wide spectrum of extra intestinal manifestation and rare autoimmune and syndromic associations. We report one such exclusive extra intestinal manifestation of celiac disease with association of Turner syndrome.
\end{abstract}

Key words: Celiac, Turner, Gluten

Table 1: Summary of Investigations

\begin{tabular}{|c|l|c|l|}
\hline S.No & Investigation & Results & Remarks \\
\hline 1 & Hemoglobin & $4.9 \mathrm{gm} \%$ & $\begin{array}{l}\text { PBS - Dimorphic } \\
\text { anemia }\end{array}$ \\
\hline 2 & Serum Iron & $29 \mu \mathrm{g} / \mathrm{dl}$ & $\begin{array}{l}\text { normal range } 50 \\
\text { to } 120 \mu \mathrm{g} / \mathrm{dL}\end{array}$ \\
\hline 3 & $\begin{array}{l}\text { Iron Binding } \\
\text { capacity }\end{array}$ & $280 \mathrm{mcg} / \mathrm{dl}$ & $\begin{array}{l}\text { normal range } \\
250-400 \mathrm{mcg} / \mathrm{dl}\end{array}$ \\
\hline 4 & $\begin{array}{l}\text { Transferrin } \\
\text { saturation }\end{array}$ & $11.1 \%$ & $\begin{array}{l}\text { normal range 25 } \\
-45 \%\end{array}$ \\
\hline 5 & Radiology & $\begin{array}{l}\text { Bone age }- \\
11-13 \mathrm{yrs}\end{array}$ & $\begin{array}{l}\text { which } \\
\text { approximates } \\
\text { the chronological } \\
\text { age but exceeds } \\
\text { the height age } \\
\text { (51/4 years) }\end{array}$ \\
\hline 6 & Urine analysis & Normal & \\
\hline 7 & Tuberculin Test & Negative & \\
\hline 8 & CXR & Normal & \\
\hline
\end{tabular}

of villi with increased intraepithelial lymphocytes).

Considering the proportionate short stature in a girl with short neck, an association of Turner Syndrome was suspected which was confirmed by Chromosome analysis (45, XO). USG abdomen revealed hypoplastic ovaries, echocardiography was within normal limit.

The child is presently being managed with gluten free diet and nutritional supplements with good response. 


\section{Discussion}

Celiac disease is an immunologically mediated small intestinal disease with a number of extra intestinal manifestations. The susceptibility is based on genetic and environmental factors. Epidemiologic studies in Europe and United States suggests that Celiac Disease may occur in $0.5 \%-1.0 \%$ of general population ${ }^{1}$. The prevalence of this disease in India has also found to be same $^{3}$.

The mode of presentation of Celiac Disease is quite variable. Acute or chronic diarrhea, abdominal pain and failure to thrive are the usual presentations, though the disease may present with extra-intestinal manifestation only. The common extraintestinal manifestations of celiac disease are short stature, iron deficiency anemia, dermatitis herpetiformis, dental enamel defects, osteoporosis, delayed puberty, arthritis and hepatitis. Other known extra-intestinal manifestations include occipital lobe epilepsy with cerebral calcifications, cerebellar ataxia, myelopathy, autoimmune myocarditis and idiopathic dilated cardiomyopathy ${ }^{4}$.

Celiac disease is rarely associated with other autoimmune disorders and genetic syndromes (Table $2)^{5,6,7,8,9}$.

Table 2: Genetic diseases associated with Celiac disease

\begin{tabular}{|c|l|c|}
\hline S.No. & \multicolumn{1}{|c|}{ Syndromes } & Association \\
\hline 1 & $\begin{array}{l}\text { Insulin Dependent Diabetes } \\
\text { Mellitus }\end{array}$ & $4.5 \%$ \\
\hline 2 & Autoimmune Thyroiditis & $7.8 \%$ \\
\hline 3 & Rheumatoid Arthritis & $2.0 \%$ \\
\hline 4 & Down Syndrome & $4.6 \%$ \\
\hline 5 & Sjogren's Syndrome & $12 \%$ \\
\hline 6 & Turner Syndrome & $5 \%$ \\
\hline
\end{tabular}

Anti-endomysium antibody $\lg \mathrm{A}$ and anti-tissue trans-glutaminase (TTG) IgA antibody are both highly sensitive \& specific in identifying individuals with Celiac Disease. Anti-gliadin IgA \& IgG are no longer recommended due to lack of specificity. Definitive diagnosis of celiac disease requires small intestinal biopsy. Revised criteria published by European Society of Pediatric Gastroenterology, Hepatology and Nutrition children with characteristic histologic features and unequivocal clinical response to gluten withdrawal can be considered definitive for celiac disease. The cornerstone of treatment for this disease remains the gluten free diet ${ }^{1,10}$.

\section{Conclusion}

Our patient showed several unusual features. Although she was primarily a case of celiac disease, no gastrointestinal manifestation was present. But a number of extra-intestinal manifestations (short stature, delayed puberty \& iron deficiency anemia) were present including the rare association with Turner's syndrome. To the best of the authors' knowledge, this has not been described in Indian literature.

\section{References}

1. Manu R. Sood. Disorders of Malabsorption. In: Kleigman RM, Behrman ER, Jenson HB, Stanton BF, editors. Nelson Text Book of Paediatrics. $18^{\text {th }}$ edition, New Delhi; Elsevier Saunders 2008: 1587 $-1593$.

2. Mäki M, Mustalahti K, Kokkonen J, Kulmala P et al. Prevalence of celiac disease among children in Finland. N Engl J Med 2003;348:2517-24.

3. Bhattacharya M, Dubey AP, Mathur NB. Prevalence of Celiac disease in north Indian children. Indian Pediatr 2009 May; 46(5):415-7.

4. K. Mustalahti, Unusual Manifestations of Celiac Disease. Indian J Pediatr 2006;73(8):711-16

5. Holmes GK. Screening for coeliac disease in type 1 diabetes. Arch Dis Child 2002;87:495-98.

6. Larizza D, Calcaterra V, De Giacomo C, De Silvestri A, Asti M, Badulli C, Autelli M, Coslovich $\mathrm{E}$ and Martinetti $\mathrm{M}$. Celiac disease in children with autoimmune thyroid disease. $J$ Pediatr 2001;139:738-40.

7. Luft LM, Barr SG, Martin LO, Chan EK, Frizler MJ Autoantibodies to tissue transglutaminase in Sjögren's syndrome and related rheumatic diseases. J Rhematol 200;30:2613-619

8. Bonamico $\mathrm{M}$, Mariani $\mathrm{P}$, Danesi $\mathrm{HM}$ et al. Prevalence and clinical picture of celiac disease in Italian Down syndrome patients: a multicenter study. J Pediatr Gastroenterol Nutr 2001;33:13943.

9. Ivarsson SA, Carlsson A, Bradberg A et al. Prevalence of celiac disease in Turner syndrome. Acta Paediatr 1999;88:933-36.

10. Fasano A, Catassi C. Current approaches to diagnosis and treatment of celiac disease: an evolving spectrum. Gastroenterology 2001;120(3):636-51. 